\title{
Methodology for the Development of Programs to Raise Competitiveness of Small and Medium Enterprises (SME) of Metal Processing Industry at the Local Level
}

\author{
Jovan Nešović ${ }^{1, *}$ - Mirko Đapić \\ ${ }^{1}$ Public Energy Company “Toplana” Kraljevo \\ ${ }^{2}$ Faculty of Mechanical and Civil Engineering Kraljevo, University of Kragujevac, Kraljevo (Serbia)
}

\begin{abstract}
Small and medium enterprises are an important factor of economic development of a local government. Today in Serbia, two thirds of the total employed people are employed in small and medium-sized enterprises. Raising the competitiveness of SMEs and metal processing industry in the coming period is a particular challenge for all actors dealing with economic development (Government, local government, chambers of commerce, NGOs, etc.). In this paper we have analyzed the methodology for the development of programs to raise competitiveness of small and medium enterprises of the metal processing industry of a local government, or more specifically in this paper, the metal processing industry of the city of Kraljevo. The analysis presented in this paper should help all those involved in local economic development, and especially the development of SMEs, which measures should be taken in the future aiming to increase the competitiveness and development of this sector, which means opening new jobs, which is very important.
\end{abstract}

\section{Keywords: Competitiveness, Small And Medium Enterprises, Economic Development}

\section{INTRODUCTION}

Small and medium enterprises (SME) have a very important role in all economies of the world, especially in transition countries and developing countries such as Serbia. In the EU, there are around 23 million small and medium-sized enterprises that employ two thirds of the total private sector and provide around $80 \%$ of new jobs. Small and medium enterprises have the same, if not greater importance for Serbia and they make 99\% of the total number of the existing enterprises which employ more than two thirds of the total number of the employed. In addition, SME account for $46 \%$ of export, $60 \%$ of import and almost $60 \%$ of private sector investments in the country [1].

Thus, small and medium enterprises are an important backbone of economic development, increasing employment and creating new jobs. Also, they are the leading participants in import and export and in the creation of gross national product. Classification within the SME sector to micro, small and medium enterprises has been done according to the number of employees, as follows: micro enterprises - number of employees up to 9, small enterprises - number of employees from 10 to 49 , medium enterprises - number of employees from 50 to 249.

Micro enterprises also include entrepreneurs, as well as physical persons who do their business activities independently [7]. Metal processing sector in the city of Kraljevo has undergone significant changes in the past 20 years, and the sector profile has changed after the privatization. Instead of large companies that have closed down or are facing the close down, the SME sector took a significant place and become one of the main driving forces of the local economy. However, the SME sector of the metal processing industry is now struggling to keep up the paste in the international market since it is facing many obstacles to export products, to conquer new markets, as well as many internal problems that burden business operation and development. In order to work systematically in the coming period to raise the competitiveness of SMEs it is required to prepare a program to support the raise of competitiveness of SMEs in the metal processing industry.

This paper defines the methodology for the development of a program for the city of Kraljevo, which is based on the methodology of developing strategic documents. The most important thing in preparing strategic documents is the inclusion of as many stakeholders. Stakeholders are representatives of national, regional and local institutions, the NGO sector, representatives of associations, businesses people, educational institutions and others.

The program is a document which development takes several months, and by implementing the activities defined therein, we can expect to raise the competitiveness of SMEs of the metal processing industry in the future should, and that means economic development of the observed area.

\section{METHODOLOGY FOR THE DEVELOPMENT OF A PROGRAM TO RAISE COMPETITIVENESS OF SME}

According to the methodology of strategic documents development, the program to raise competitiveness of small and medium enterprises (SME) of the metal processing industry consists of five phases as follows: preparatory phase, condition analysis, strategic framework, action plan and implementation plan (Figure 1.). 


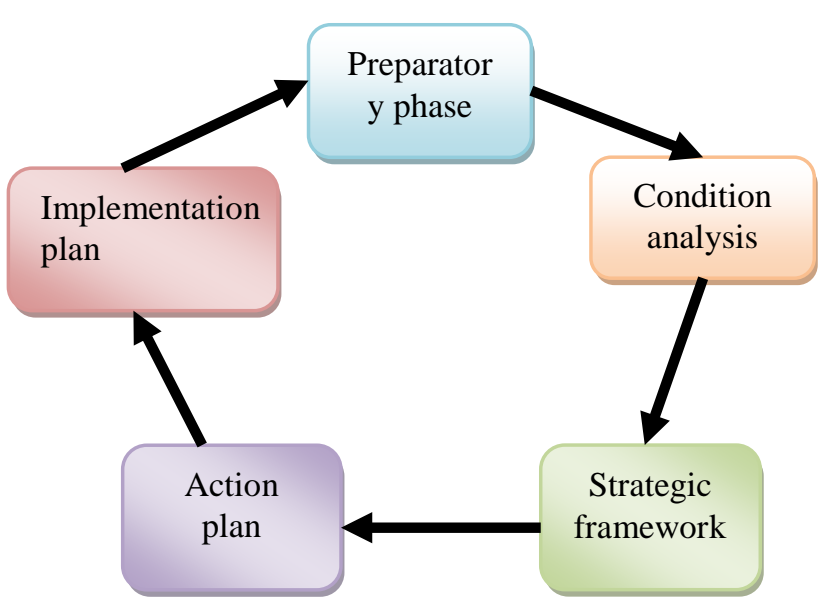

Figure 1. Graphic presentation of phases in the development of a Program to raise competitiveness of metal processing industry SMEs

\section{a) Preparatory phase}

This phase includes two steps - plan preparation arrangement and inclusion of stakeholders. The plan preparation arrangement is very important because the development of this program requires the support of a certain institution, which is a political support most often. Such institution may be a local government, several local governments, chambers of commerce, associations, state institution or other. In this phase, it is important to appoint a person - plan development coordinator who is able to deliver this job with their knowledge, experience, organization skills. In addition, it is important in this phase to form a working group that will work on the plan development, and a detailed budget required for the overall period of work on this project.
The working group should comprise of representatives of state institutions, chambers of commerce, business sector (companies), associations dealing with industry and educational institutions. Stakeholder engagement is a key aspect of a participatory approach of the development of the Program to raise the competitiveness of SMEs.

Stakeholders are individuals, groups, institutions from the public and private sector, development agencies, associations, businesses and others. All of them, with their knowledge, the information they possess and their expertise should give full contribution to the development of this plan. Particular attention should be paid to include as many representatives of SMEs because they best know the issues and the needs of this sector. It often happens that the stakeholders need be particularly motivated, and there lays a significant role of the coordinator. This is usually achieved by direct contact, an official invitation or through the media via the Program significance campaign.

\section{b) Condition analysis}

This work to be done by the working group, while the stakeholders need to give their suggestions and proposals. The data collected in this phase should enable the preparation of SWOT analysis and conceptualization of the problem tree related to raising competitiveness. The problem tree puts light on the causes, consequences and challenges the SME is facing (Figure 2). Collection of data at this stage may be from various sources, organizations, and individuals. These are official data of certain institutions, but it is very important to collect data from the very SMEs. This is done mostly through a special questionnaire and direct contact with elected representatives of SMEs. When data is collected and processed, we receive a summary results presented as charts, tables and the like. All this should help the working group to develop a SWOT analysis and the problem tree, which should be the foundation for making a clear, precise and achievable strategic framework and action plan.

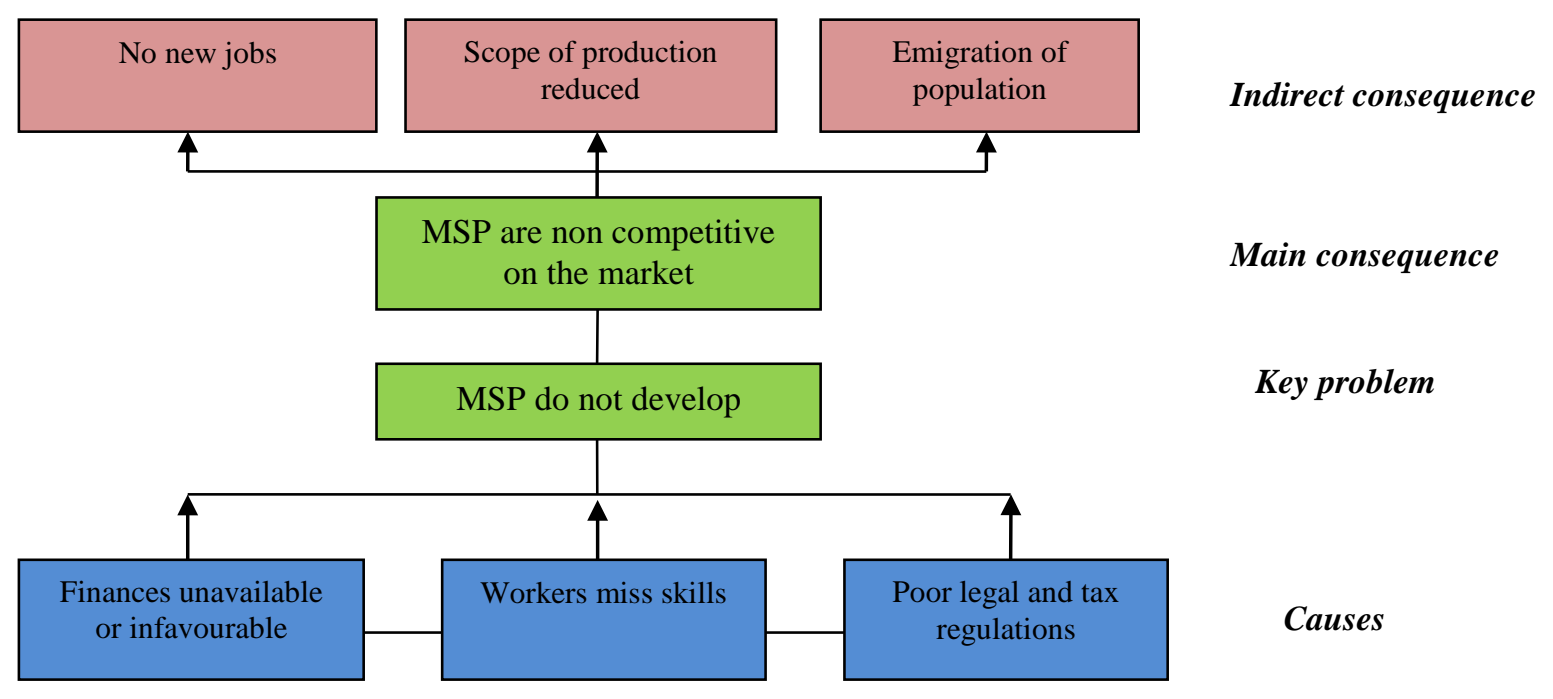

Figure 2. Schematic view of the problem tree in the preparation of the Program to Raise Competitiveness of SME 


\section{v) Strategic framework}

After understanding (Figure 2) the current competitiveness of the metal processing sector SMEs, it is necessary that the working group defines the desired position of SMEs in the future period (vision) and the way in which this position can be achieved (by defining priorities and objectives). It is important that all members of the working group participate in the operation and give their full contribution. Vision of the program often refers to removing barriers for the operation of SMEs, as well as the measures that need to raise their competitiveness.
It should be such as to creates a favorable environment that will remove or alleviate the difficulties defined in the problem tree. Strategic goals and specific objectives are defined at this stage (Figure 3)

The strategic goals represent the end point or the position we want to achieve in relation to a particular issue (e.g. Establishment of an institutional unit that helps SMEs in the metal processing industry in terms of funding access). Specific objectives are the specific results that should result in the implementation of projects within the program (e.g. Support for $10 \%$ of SMEs in obtaining favorable funding). These objectives are the indicators by which progress, the effect or the like in the implementation of the plan can be measured.

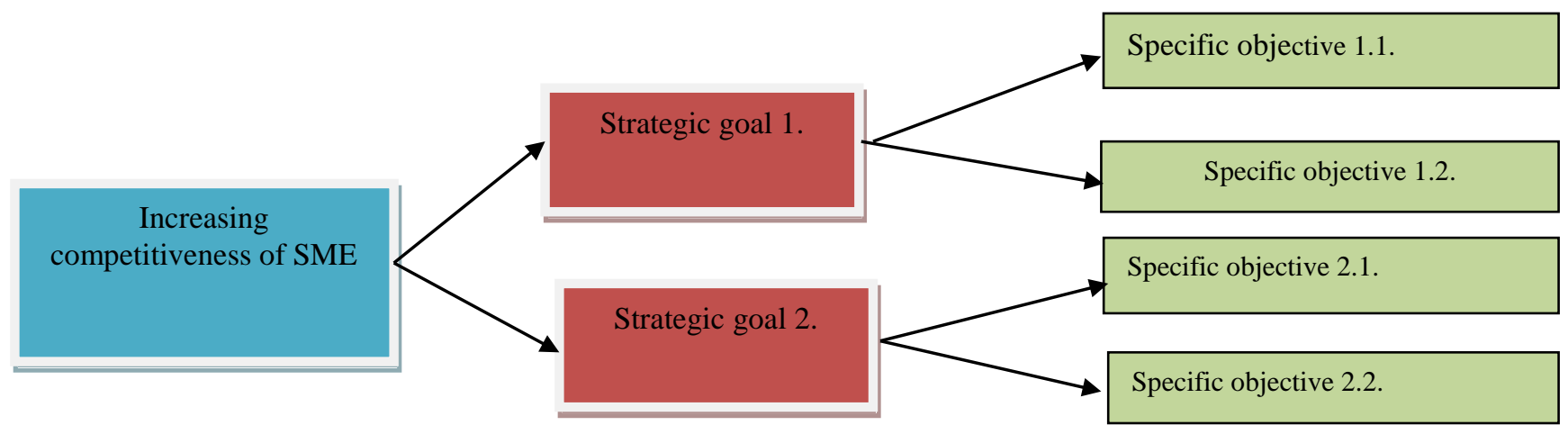

Figure 3. Graphical display of priorities, strategic and specific objectives

\section{g) Action plan}

After defining the strategic framework, the working group should prepare the Action plan. The plan defines the steps to be taken (projects to be implemented) in order to achieve the set objectives (strategic and operational). These steps involve changing the existing policies towards SMEs and implementation of specific projects. Most of these projects aimed to create favorable environment where SME can grow and develop, and become more competitive in the market. This process requires a lot of time and effort.

First, it is necessary to make a list of proposed projects and then to determine their priorities and sequencing. It is often necessary to make a table that shows the priority order of projects and the time required for implementation (assumed beginning and end). Here it is necessary to explain and interconnectivity between the projects, i.e. a situation where the beginning of a project depends on the completion of another. The whole process of developing the Programs to Raise Competitiveness of SMEs can be displayed with use of algorithm (Fig. 4).

\section{f) Program implementation and evaluation}

It is essential to determine the sector (service) in local government which is responsible for the implementation of the program. The main problem in this activity is the lack of financial resources at the local level.
Priority projects should find their place in the budget of the local government, but it is also required to seek funding from external sources. The projects proposed projects for external funding must be described in detail and convincing.

Also, their strategic importance and connections to regional and national development priorities must be recognized. It is important to establish cooperation with regional development agencies, chambers of commerce, central government bodies, donors and other local governments for the purpose of joint appearance in the realization of certain projects.

It is important in this program to include representatives of SME because they can significantly contribute to the promotion of the program and securing funds for implementation.

Monitoring of the program implementation should lead to improved efficiency and effectiveness. For this purpose it is necessary to appoint a person in charge of monitoring and reporting, and to define procedures by which such job is executed. Monitoring involves collecting and processing data that enable reporting on the program success indicators.

It is important that this report is considered and adopted by a local government body, and our proposal is that that body should be the City Council. 


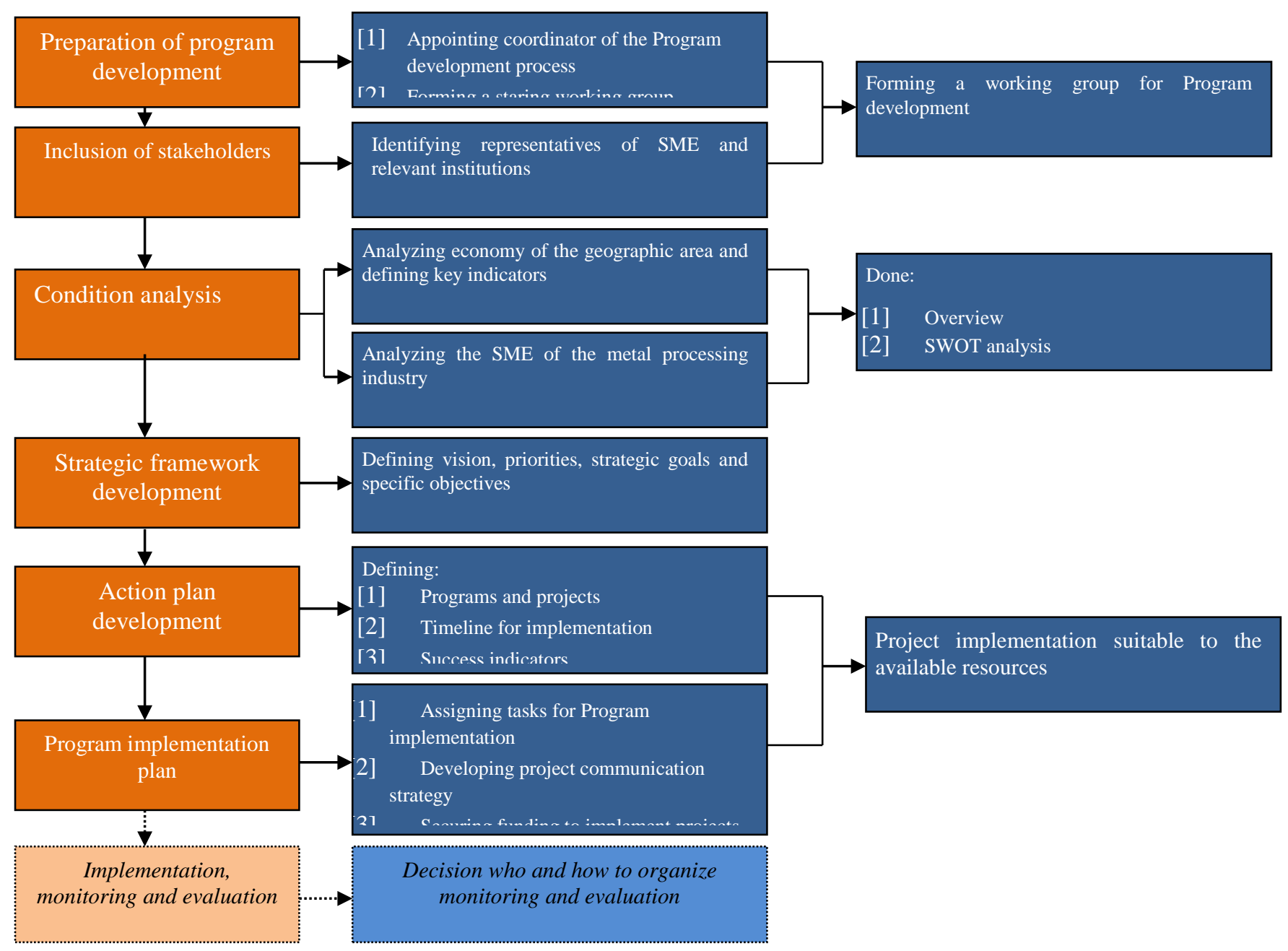

Figure 4. Schematic view of the development process of the Program to Raise Competitiveness of SME in the metal processing industry

\section{PROGRAM TO RAISE COMPETITIVENESS OF SME IN THE CITY OF KRALJEVO}

Analyzing the City of Kraljevo Development Strategy 2020, and in particular the part of the projects proposed in the action plan related to the strategic goal "Building sustainable competitive knowledge-based economy and rational use of available resources", projects that can be found in the program to raise competitiveness of SME in the metal processing industry of the city of
Kraljevo may be defined. Only a couple of projects are shown here, following the methodology set forth previously, and a part of the action plan is presented in Table 1. The program should certainly be a comprehensive, strategic document and we hope that the local government will work on its development. All these activities should be the aim of the system development of $\mathrm{SME}$ and the overall economic development of the local government.

Table 1. Part of the action plan to raise competitiveness of SME in the city of Kraljevo

\begin{tabular}{|l|l|}
\hline \multicolumn{2}{|c|}{$\begin{array}{c}\text { Raising competitiveness of SME of the metal processing industry in the city of Kraljevo } \\
\text { Strategic goal: } 1 \text {. Institutional support to development and business operation }\end{array}$} \\
\hline \multicolumn{1}{|c|}{ Specific objective: 1.1. Better quality of services for SME } \\
\hline Number & Project \\
\hline 1.1 .1$. & Modernization of utility services \\
\hline 1.1 .2$. & Modernization of state administration \\
\hline \multicolumn{2}{|c|}{ Specific objective: 1.2 . Developing systematic support to SME } \\
\hline Number & Project \\
\hline 1.2 .1$. & Establishing a local fund for the development of entrepreneurship and MSP \\
\hline 1.2 .2$. & Preparing a local package of benefits for the SME (taxes, fees, etc.) \\
\hline
\end{tabular}




\begin{tabular}{|l|l|}
\hline \multicolumn{2}{|c|}{ Strategic goal: 2. Improving the existing business infrastructure } \\
\hline \multicolumn{1}{|c|}{ Specific objective: 2.1. Revitalization of Brownfield locations } \\
\hline Number & Project \\
\hline 2.1 .1$. & Developing revitalization studies for Brownfield locations \\
\hline 2.1 .2$. & Arranging, equipping and promotion of Brownfield locations to potential investors \\
\hline \multicolumn{2}{|c|}{ Specific objective: 2.2. Constructing new business infrastructure } \\
\hline Number & Project \\
\hline 2.2 .1$. & Preparing a feasibility study on the establishment of an Innovation Center in Kraljevo \\
\hline 2.2 .2$. & Establishing the Innovation Center in Kraljevo \\
\hline
\end{tabular}

\section{CONCLUSION}

In the next period, small and medium enterprises should be the holder of development of many local governments in the Republic of Serbia. The SME sector can bring serious economic growth, employment, and therefore create better living conditions for citizens. This requires all stakeholders (government, local government, Chambers of Commerce, Agencies dealing with the development of this sector, etc.) to pay special attention to the development and rising of competitiveness of this sector of economy. This paper provides a brief methodology for the development of a program to raise competitiveness of SMEs in a local government. The program is a systematic approach in development support and should enable rational spending of public funds on one hand, and achieving the best possible competitiveness effects on the other hand. We herewith want to indicate the importance of enacting this program in the future period to all the decision makers at the local level.

\section{REFERENCES}

[1] dr Nicholas Miles, Toby Philpott, Zorana Bilić, dr Klaus Richter "Izrada planova podrške razvoja malih i srednjih preduzeća i preduzetnika na lokalnom nivou" Beograd, 2012.

[2] Jelena Bojović „Lokalni ekonomski razvoj - priručnik za praktičare" THE URBAN INSTITUTE, Beograd 2010.

[3] "Metodologija izrade strategija odživog razvoja”, SKGO/EXCHANGE 2, Beograd 2009.

[4] Zakon o lokalnoj samoupravi, Službeni glasnik RS 129/2007.

[5] Akt o malim preduzećima "Mislite pre svega na mala preduzeća" dostupan na adresi: www.eur-lex.europa.eu

[6] mr Ljiljana Brdarević „Razvoj lokalne infrastrukture kroz javno-privatna partnerstva, priručnik za lokalne vlasti“ USAID program za Srbiju 2012.

[7] M. Živanić "Primena poslovnog reinženjeringa na razvoj malih i srenjih preduzeća" FBIM Transaction (159 - 168), 2013.

[8] Dokument "Strateški plan razvoja grada Kraljeva 2014-2020”, Kraljevo, 2015.

[9] S. Ikić, F. Gudžević "Perspektive razvoja malih i srednjih preduzeća u Novom Pazaru", Treća međunarodna koferencija - Savremena znanja i novi izvori energije u funkciji društveno-ekonomskog razvoja, Novi Pazar, 2012. 